\title{
Staged treatment of an intra-articular fracture of the distal tibia with a modified intramedullary nail (case study)
}

\author{
E.V. Pomogaeva ${ }^{1}$, E.A. Volokitina ${ }^{1}$, S.M. Kutepov ${ }^{1}$, Iu.V. Antoniadi ${ }^{1}$, F.N. Zverev ${ }^{2}$ \\ ${ }^{1}$ Ural State Medical University, Ekaterinburg, Russian Federation, \\ ${ }^{2}$ Central City Clinical Hospital No 24, Ekaterinburg, Russian Federation
}

\begin{abstract}
Introduction The severity of intra-articular fractures of the distal tibia results from the morphological features of this segment, and therefore, bone injury is combined with trophic soft tissue disorders. Open reduction and internal fixation have a negative effect on reparative processes in the local morphological structures, and complications such as soft tissue necrosis, infection, infected and deforming osteoarthritis, or nonunion may develop. The aim was to show a clinical case of a stage-bystage treatment of an intra-articular fracture of the distal tibia using minimally invasive methods, reduction with the Ilizarov apparatus and closed intramedullary osteosynthesis with a modified ChM nail. Results and discussion The Ilizarov apparatus was used for primary reduction and stabilization of the fracture that enabled to eliminate gross displacements and to align the axis of the segment. After the edema had ceased and soft tissue condition improved, closed intramedullary osteosynthesis was implemented with a modified ChM nail. Conclusion A staged approach to manage intra-articular fractures of the distal tibia enables to avoid additional soft tissue trauma and results in good clinical outcomes. The available metal intramedullary implants for intra-articular fractures are imperfect, but their modification may improve stability and decrease the risks of postoperative complications if the number of holes for locking is increased.
\end{abstract}

Keywords: fracture, distal tibia, Ilizarov apparatus, intramedullary osteosynthesis

\section{INTRODUCTION}

Distal tibia fractures associated with injuries of the articular surface is a complex task for an orthopaedic surgeon in terms of choosing the treatment option. The combination of bone and soft tissue trauma which is characteristic for such type of fractures does not always allow choosing a fixation method that will be optimal for the reparative process [1,2].

The basic tactics of treating intra-articular fractures of the distal tibia (IAFDT) involves an open reconstructive intervention aimed to most accurately restore the anatomy of the joint. However, open reduction (OR) and internal fixation (IF) is associated with a number of complications, such as soft tissue necrosis, infection and the development of purulent osteoarthritis, and slow consolidation.
According to the data of L.N. Rubekina et al. (2010) [3], deforming arthrosis of the ankle joint of varying severity was recorded in $38 \%$ of cases following three to five years after surgery; delayed consolidation and pseudarthrosis were found in $10 \%$ and $3 \%$ of cases, angular deformities of the lower leg and osteomyelitis in $8 \%$ and $9 \%$ of cases, respectively. Complications in the early and long-term period and low functional outcomes after surgical interventions make the trauma surgeons search for more effective and less invasive methods of surgical treatment of these fractures $[4,5]$.

Purpose To demonstrate a clinical case of a staged treatment of an intra-articular fracture of the distal tibia using the Ilizarov method and closed intramedullary osteosynthesis with a modified ChM nail.

\section{MATERIAL AND METHODS}

Patient B., 60 years old, sustained a fracture falling from a height of about three meters. At admission, she complained of pain in the right ankle joint and functional restriction in the right lower limb. The axis of the right lower limb was not mal-aligned visually.
The skin was intact and was rated grade 0 according to the classification of H.G. Tcherne and L. Gotzen (1984) [6]. In the lower third of the right lower leg, ankle joint and foot there was a moderate swelling. Palpation and axial loading revealed severe pain in the ankle joint.

Pomogaeva E.V., Volokitina E.A., Kutepov S.M., Antoniadi Iu.V., Zverev F.N. Staged treatment of an intra-articular fracture of the distal tibia with a modified intramedullary nail (case report). Genij Ortopedii, 2019, vol. 25, no 4, pp. 569-575. DOI 10.18019/10284427-2019-25-4-569-575. (In Russian) 
There was neither crepitation nor pathological mobility. Movements in the right ankle joint were restricted and painful. Peripheral neurological and ischemic disorders in the limbs were not detected at the examination.

At each stage of the examination and treatment, $\mathrm{X}$-rays of the right ankle joint were taken in two projections and measurements were done to objectify the findings (Fig. 1). Values of the distal epidiaphyseal angle (DEA) were found and compared with the values of the reference lines and angles for the ankle joint described in the manual of L.N. Solomin and K.L. Korchagin [7]. Computed tomography was used to clarify the morphology of the injury and the reduction quality.

The admission radiographs of the right lower leg and ankle joint revealed a fracture of the distal epimetaphysis of the right tibia with a defect in bone tissue along the anterior surface of the tibia in the metaphyseal zone. According to AO/ASIF classification, the fracture corresponded to type $\mathrm{C} 1$. Given the swelling in the lower third of the leg, a two-stage treatment tactic was chosen. The first step was fixation of the lower leg and foot in the distraction module of the Ilizarov apparatus consisting of two supports. Two wires were inserted through the metaphysis of the tibia proximally and fixed in the ring of the Ilizarov apparatus; distally there two wires in the calcaneus, fixed in $3 / 4$ of the ring. Distraction along three telescopic rods corrected the displacements and restored the axis of the segment. Moreover, the fixation of the lower leg in the Ilizarov apparatus allowed the patient to be active from the first hours after the injury. Radiographs of the right lower leg and ankle joint in two projections before and after the Ilizarov fixation are shown in Figure 1. The DEA before fixation of the lower leg bones in the AEF in the sagittal plane was 95.6 degrees which is 6.6 degrees more than the norm; in the frontal plane it measured 63.4 degrees which is 16.6 degrees less than the norm. $\mathrm{X}$-ray measurement data after fixation of the lower leg in AEF revealed the DEA in the sagittal plane equal to 89.3 degrees and 82.3 degrees in the frontal plane. The results of reduction were positive as the position of the fragments along the axis was satisfactory, and the DEA was close to the reference values (Fig. 1).

Five days later, after the edema in the region of the right lower leg and the ankle joint had reduced, the CIMO of the right tibia using a modified ChM nail with static locking was performed. The standard tibial ChM nail with distal multi-axial locking has three holes for locking in the proximal part, including one oval; there are five holes in different planes in the distal part. The size range meets the requirements for intramedullary rods.

In order to more accurately diagnose the morphology of the fracture, CT scanning of the right ankle joint was performed with the Ilizarov apparatus on the limb (Fig. 2).

In order to enhance the stability of fixation, we proposed a modified intramedullary ChM nail, which is supplied with holes in addition to five standard distal holes (below the horizontal plane of the fracture); two holes were formed in the sagittal direction at a distance of 1.00 and $2.5 \mathrm{~cm}$ above the horizontal plane of the fracture. Fixation through additional holes prevented the displacement of bone fragments. Figure 3 shows a diagram of intramedullary osteosynthesis of the intraarticular fracture of the distal tibia with the modified nail, as well as a model of a distal tibial fracture and its osteosynthesis with a modified nail with five screws for multi-axial locking in various directions.
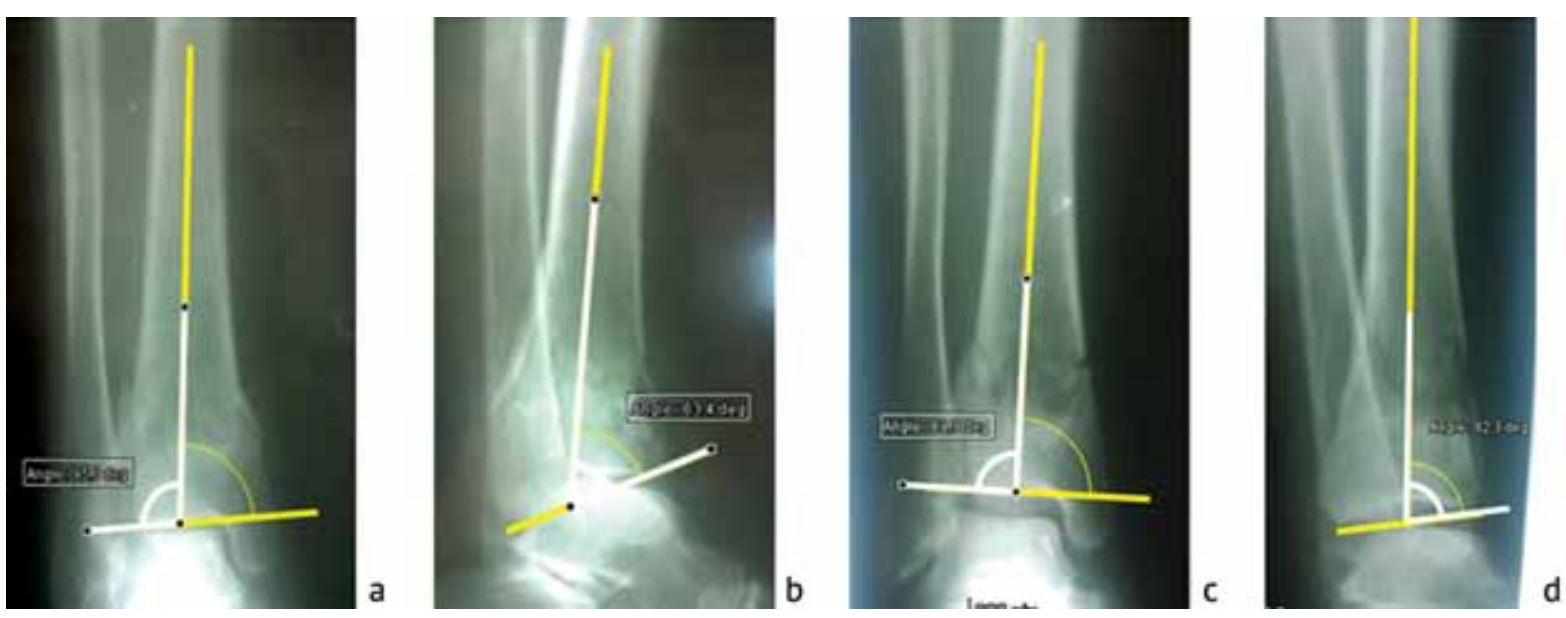

Fig. 1 Radiographs of the right ankle joint and the right lower leg of patient B., 60 years old, direct (a) and lateral (b) views, prior to fixation in the Ilizarov apparatus module; direct (c) and lateral views $(\boldsymbol{d})$ after fixation in the Ilizarov apparatus 

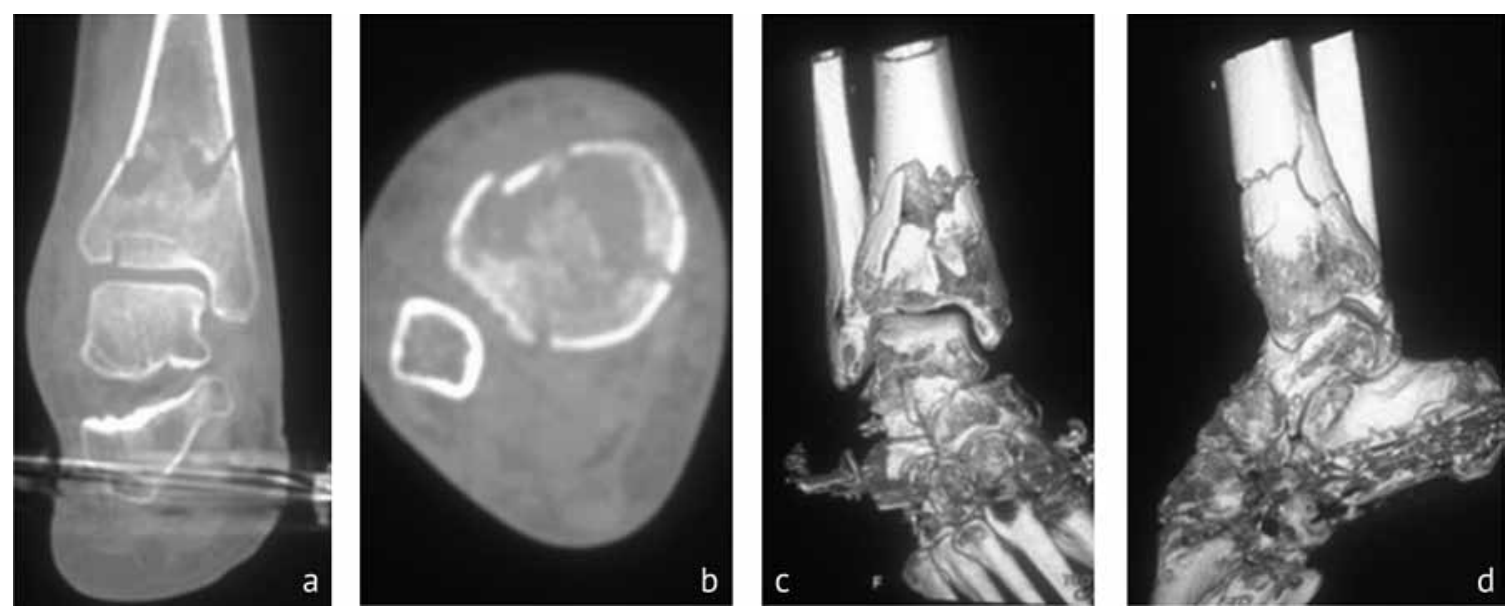

Fig. 2 CT scans of the right ankle joint and of the right lower leg bones in patient B., 60 years old; fixation of the bones of the right lower leg in the Ilizarov apparatus on the segment: sagittal section $(\boldsymbol{a})$, horizontal section $(\boldsymbol{b})$; 3D reconstruction of the distal tibia $(\boldsymbol{c}, \boldsymbol{d})$ shows a type $\mathrm{C} 1$ comminuted fracture of the distal epimetaphysis of the right tibia and damage to anterolateral Tillaux-Chaput tubercle
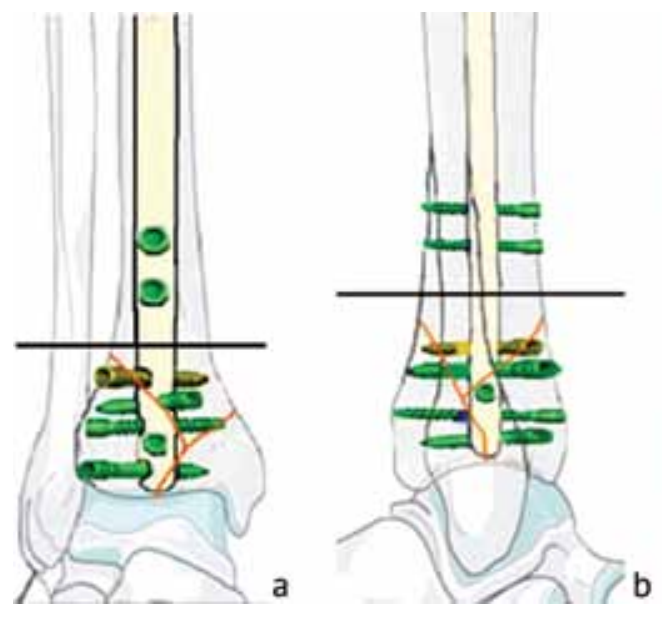
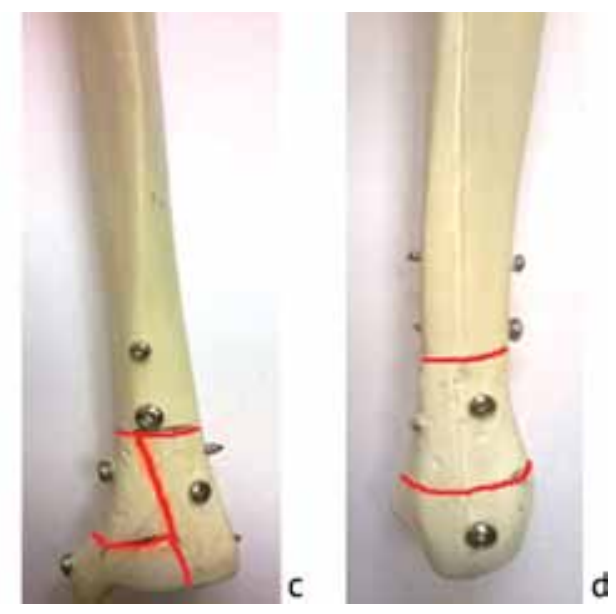

Fig. 3 Diagram of intramedullary osteosynthesis ( $\boldsymbol{a}$ anteroposterior and $\boldsymbol{b}$ lateral views) with two screws in the anteroposterior direction inserted through additional holes above the horizontal plane of the fracture. Photo of a bone model of a fracture of the distal tibia epimetaphysis and its intramedullary fixation (c anteroposterior and $\boldsymbol{d}$ lateral views)
The technology of intramedullary osteosynthesis of the distal tibia did not differ in its main stages from the osteosynthesis of a diaphyseal fracture. Under spinal anesthesia and the patient supine, residual displacements were reduced by a closed method with the Ilizarov apparatus on, and the fragments were temporarily fixed with wires. The entry point for the nail was formed along the anterior surface in the proximal tibial epimetaphysis at the border with the joint. A canal in the tibia was prepared, then the nail was introduced into the tibia. The nail was locked through three standard distal openings (below the fracture) and through two additionally holes (above the fracture) (Fig. 4).

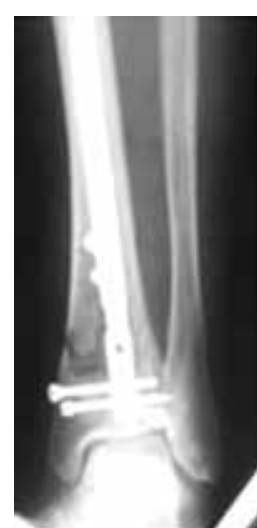

a

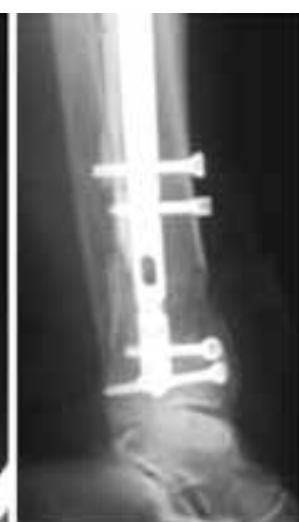

b

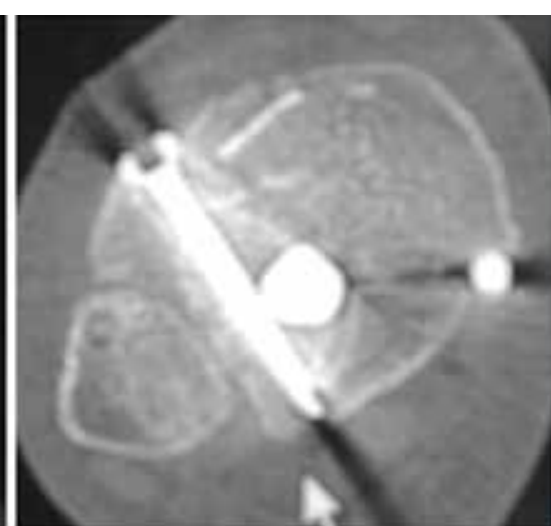

c

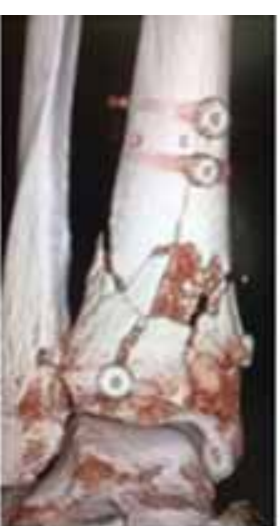

d

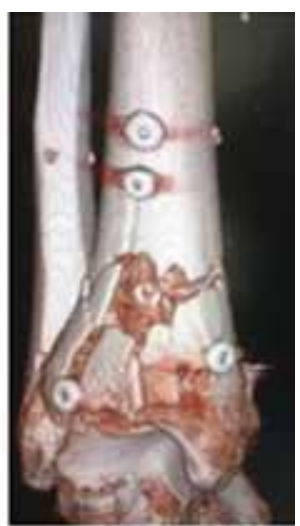

e

Fig. 4 Radiographs of the right ankle joint and the right lower leg of patient B., aged 60, direct (a) and lateral (b), after surgical treatment showing that residual displacements were eliminated, the axis of the segment was normalized, congruence of the articular surface was achieved; $\boldsymbol{c}, \boldsymbol{d}, \boldsymbol{e}$ control CT scans of intramedullary osteosynthesis of the distal tibia epimetaphysis showing a satisfactory position of the fragments and metal fixators 
Prior to CIMO with the modified nail, the fracture in the area of the distal anterior Chaput tubercle was reduced and fixed with temporal wires. Upon nail locking, the tubercle was screwed outside the nail.
CT checked the position of the nail in the distal tibia. Figure 4 shows a 3D-reconstruction of the distal tibia upon fixation with the nail and a horizontal scan at the level of the screw to fix the Chaput tubercle.

\section{RESULTS}

Figure 5 are radiographs of patient B., 60 years old, 12 months after surgical treatment. The fracture consolidated without secondary displacement of the fragments. At 12-month follow-up, the function of the ankle joint was good; the patient was active and walked fully loading the right lower limb and did not limp. The mid-term (6 months) and long-term (12 months) scores on the scale of E. Mazur (2010) [8] were 78 and 84 points, respectively. The outcome was rated as excellent (Fig. 5).
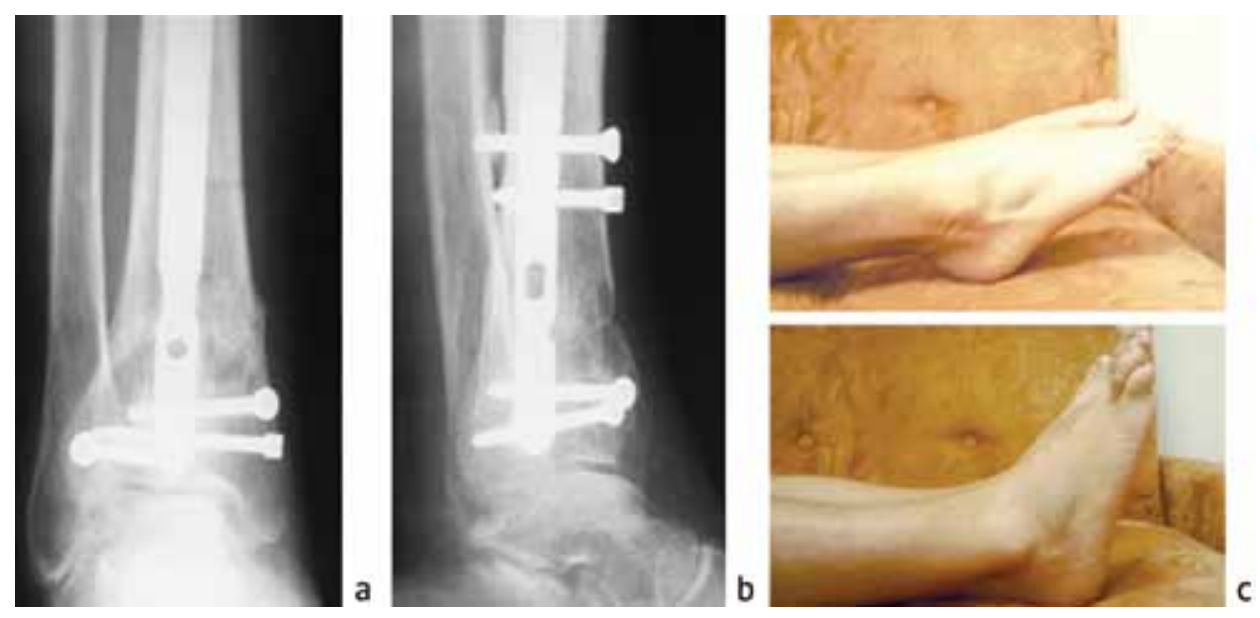

Fig. 5 Radiographs of the right ankle joint and the right lower leg bones of patient B., 60 years old, direct (a) and lateral (b), 12 months after surgical treatment. Photo of the right ankle joint $(\boldsymbol{c})$ showing a full range of motion achieved

\section{DISCUSSION}

According to the AO/OTA classification [9], intraarticular fractures of the distal tibia is a heterogeneous group of injuries from relatively mild fractures type $43 \mathrm{~B} 1$ and $43 \mathrm{C} 1$ to fractures of type $43 \mathrm{~B} 3$ and $43 \mathrm{C} 3$ that are complex, comminuted, and often associated with severe soft tissue damage. Surgical treatment of any fracture of this location should meet a number of requirements which are restoration of the axis and length of the fibula, restoration of the articular surface of the tibia, repair of defects in the metaphysis and stable fixation. The method of open reduction and internal fixation meets all four requirements [10, 11, 12]. In the recent decades, a fifth requirement has prevailed over the four principles which says that the choice of a specific treatment method should be determined by the condition of distal tibia soft tissues. Therefore, researchers have been exploring an alternative to open reduction and internal fixation methods, among which is a two-stage treatment tactics [13 ] and new possibilities of IMO (intramedullary osteosynthesis), especially in older people with thin skin or damaged soft tissues, as well as in patients at high risk of wound healing failure.
In the early posttraumatic period, the solution to the problem of soft tissue healing is a two-stage treatment tactics, which involves external fixation at the first stage followed by changing to internal osteosynthesis as the second stage of treatment. This approach enables to restore the segment axis early after the injury, to eliminate gross displacements of fragments, and, as a result, to level the internal damage to soft tissues with the fragments $[14,15,16]$. Our method of temporary fixation of intra-articular fractures using the distraction module of the external fixation device meets the above requirements (RF patent No. 2564080).

Postoperative wound healing in the patients with intra-articular fractures of the distal tibia might be solved with low-invasive treatment methods at the second stage, in particular, with intramedullary osteosynthesis.

Classical variants of intramedullary osteosynthesis have been considered to be the "gold" standard for repair of diaphyseal fractures of long bones. The available on the market intramedullary nails with proximal and distal multi-axial locking using screws 
have expanded the indications for intramedullary osteosynthesis to periarticular fractures. The question of using intramedullary osteosynthesis in intraarticular fractures seems logical [17].

Publications devoted to the intramedullary osteosynthesis of intra-articular fractures of the distal part of the lower leg bones are scarce. A significant part of the literature is devoted to the techniques of intramedullary osteosynthesis of extra-articular tibial fractures [17]. In some cases, authors that used IMO for fixation of metaphyseal fractures admit that a fracture line extending from the metaphysis to the articular surface without impression of the latter (fracture type $43 \mathrm{~B} 1$ ) can be considered as a fracture type 43A and, accordingly, be treated in a similar way [18 ].

Among the publications on the synthesis of intraarticular fractures of the distal tibia, there are also studies regarding the benefits of choosing either a plate or a nail. In 2014, X.H. Xue et al. [19] conducted a meta-analysis and systemic review comparing a nail and a plate for management of metaphyseal fractures of the distal tibia and found a higher functional score and lower risk of infection in the group of patients treated with nails. The research of S. Kumar et al. (2018) [20] confirmed their findings.

In 2019, a group of authors published data on a meta-analysis comparing the efficiency of two methods of fixation, plating and nailing, in the treatment of distal metadiaphyseal fractures of the tibia with and without involvement of the articular surface [21]. The authors concluded that plating and nailing are two effective osteosynthesis methods for repair of periarticular fractures. However, complications observed by nailing were pain in the knee joint and a higher risk of deformity at the fracture level. But the risk of wound infection was higher in using the methods of open reduction and internal fixation.

The use of IMO for intra-articular fractures is usually indicated for fractures of type $43 \mathrm{~B} 1$,
B2 and fractures of type 43 C1 and C2 which are not associated with a severe damage to the articular surface and for which open reduction of the articular fragments may not be a need. In such cases, intramedullary osteosynthesis requires careful preoperative planning and surgeon's experience in closed reduction of fragments. Moreover, standard nail designs for the synthesis of such distal fractures are imperfect, since they do not consider the anatomy of the articular ends. In the area of the intramedullary canal transition from the narrow zone of the tibia to the distal metaepiphysis (wide zone) the nail mismatches the inner space of the tibia, which causes instability of the structure, the so called effect of a "pencil in a glass". It can result in early instability and secondary displacement of bone fragments [22]. In particular, M.S. Marcus et al. (2013) evaluated the results of intramedullary osteosynthesis in 31 patients with fractures of the distal lower leg bones (fractures corresponded to type $43 \mathrm{C} 1-\mathrm{C} 2$ ). The complications found by the authors were one nonunion, one case of delayed consolidation, one case of thrombosis and two cases of infectious complications [23]. The authors recommended the use of off-rod screws to enhance the stability of osteosynthesis.

The modification of the ChM nail proposed that has two holes in the sagittal direction at a distance of 1.00 and $2.5 \mathrm{~cm}$ above the horizontal plane of the fracture increases the stability of fixation to prevent secondary displacement of bone fragments.

Given the rare incidence of fractures of types $43 \mathrm{~B}$ and $43 \mathrm{C}$, as well as even a rarer occurrence of fractures for which the method of intramedullary osteosynthesis would be indicated, further study of this topic requires large-scale prospective randomized studies. So, our experience of intramedullary osteosynthesis of intra-articular fractures of the distal tibia may be useful for the development of this minimally invasive technique.

\section{CONCLUSION}

We opine that the staged approach to managing intra-articular fractures of the distal tibia that are anatomically complex using minimally invasive methods of distraction osteosynthesis with the Ilizarov apparatus and closed intramedullary osteosynthesis with a modified ChM nail is reasonable and low-traumatic. Modification of the IMO nails by increasing the number of holes for locking in the distal bone portion (over the fracture plane) is aimed to reduce the risks of postoperative complications, improve fixation stability and obtain good results. 
Conflict of interests The authors declare no apparent and potential conflicts of interest related to the publication of this article.

Source of funding The study was conducted as a part of the state assignment for research and development by the department of traumatology and orthopedics of the Central Scientific Research Laboratory of the Federal State Budget Educational Institution of Higher Medical Education of the Ural State Medical University of the Ministry of Health of Russia.

Compliance with ethical principles The study design was approved by the ethics committee of the Federal State Budget Educational Institution of Higher Medical Education of the Ural State Medical University of the Ministry of Health of Russia.

\section{REFERENCES}

1. Lomax A., Singh A., Jane M.N., Senthil K.C. Complications and early results after operative fixation of 68 pilon fractures of the distal tibia. Scott. Med. J., 2015, vol. 60, no. 2, pp. 79-84. DOI: 10.1177/0036933015569159.

2. Sitnik A.A., Beletsky A.V. Minimally invasive percutaneous plate fixation of tibia fractures: results in 80 patients. Clin. Orthop. Relat. Res., 2013, vol. 471, no. 9, pp. 2783-2789. DOI: 10.1007/s11999-013-2841-x.

3. Rubekina L.N., Babovnikov A.V. Opyt operativnogo lecheniia pilonnykh perelomov na kafedre travmatologii, ortopedii i voennopolevoi khirurgii MGCMY [The experience of surgical treating pilon fractures at the Department of Traumatology, Orthopaedics and Military Surgery of Moscow State University of Medicine and Dentistry]. Mezhdunarodnaia Iubileinaia Nauchno-prakticheskaia Konferentsiia «Sovremennye povrezhdeniia $i$ ikh lechenie», posviashchennaia 200-letiiu so dnia rozhdeniia N.I. Pirogova: materialy [Proc. International Anniversary Scientific Practical Conference "Modern Injuries and their Treatment", dedicated to $200^{\text {th }}$ anniversary of N.I. Pirogov's birth]. M., 2010, pp. 158-159. (in Russian)

4. Chermakov K.S. Sposob maloinvazivnogo osteosinteza svezhikh perelomov zadnego kraia bolshebertsovoi kosti s pomoshchiu reponiruiushchego apparata [The way of minimally invasive osteosynthesis for recent fractures of the tibial posterior end using a reposition device]. Zhurnal Nauchnykh Publikatsii Aspirantov i Doktorantov (Kursk), 2009, no. 12, pp. 154-155. (in Russian)

5. Kondratev I.P. Metod nakostnogo osteosinteza perelomov kostei distalnogo otdela goleni odnim fiksatorom iz edinogo dostupa [The method of extra-cortical osteosynthesis for fractures of the distal leg with a single fixator from a single access]. Medline.ru. Rossiiskii Biomeditsinskii Zhurnal, 2012, vol. 13, no. 3, pp. 716-725. (in Russian) Available at: http://www.medline.ru.

6. Oestern H.-J., Tscherne H. Pathophysiology and classification of soft tissue injuries associated with fractures. Tscherne H., Gotzen L., eds. Fractures with Soft Tissue Injuries. NY, Springer-Verlag, 1984, pp. 1-9.

7. Solomin L.N., Shchepkina E.A., Kulesh P.N., Vilenskii V.A., Korchagin K.L., Skomoroshko P.V., comp. Opredelenie referentnykh linii i uglov dlinnykh trubchatykh kostei: posobie dlia vrachei [Determination of reference lines and angles of long tubular bones: a guide for physicians]. $2^{\text {nd }}$ Ed. SPb., RNIITO im. R.R. Vredena, 2012, 48 p. (in Russian)

8. Boraiah S., Kemp T.J., Erwteman A., Lucas P.A., Asprinio D.E. Outcome following open reduction and internal fixation of open pilon fractures. J. Bone Joint Surg. Am., 2010, vol. 92, no. 2, pp. 346-352. DOI: 10.2106/JBJS.H.01678.

9. Müller F.J., Nerlich M. Tibial pilon fractures. Acta Chir. Orthop. Traumatol. Cech., 2010, vol. 77, no. 4, pp. 266-276.

10.Rüedi T. Fractures of the lower end of the tibia into the ankle joint: results 9 years after open reduction and internal fixation. Injury, 1973, vol. 5, no. 3, pp. 130-134. DOI: 10.1016/s0020-1383(73)80089-0.

11.Müller M.E., Allgöwer M., Schneider R., Willenegger H. Manual of Internal Fixation. Techniques Recommended by the AO-ASIF Group. Ed. by M. Allgöwer. Berlin, Heidelberg, Springer-Verlag, 1991. 752 p. (Russ. ed.: Miuller M.E., Algover M.A., Shnaider R., Villineger Kh. Rukovodstvo po vnutrennemu osteosintezu: Metodika, rekomendovannaia gruppoi AO. M., Ad Marginem, 1996, $780 \mathrm{p}$.

12.Krettek C., Bachmann S. Pilon fractures. Part 1: Diagnostics, treatment strategies and approaches. Chirurg, 2015, vol. 86, no. 1, pp. 87-101. DOI: 10.1007/s00104-014-2895-7.

13.Sirkin M., Sanders R., DiPasquale T., Herscovici D. Jr. A staged protocol for soft tissue management in the treatment of complex pilon fractures. J. Orthop. Trauma, 2004, vol. 18, no. 8 Suppl., pp. S32-S38.

14.Slastinin V.V., Kliukvin I.Iu., Filippov O.P., Bogoliubskii Iu.A. Vnutrisustavnye perelomy distalnogo otdela bolshebertsovoi kosti: evoliutsiia vzgliadov na khirurgicheskoe lechenie (obzor literatury) [Intra-articular fractures of the distal tibial part: evolution of surgical treatment views (Review of the literature)]. Zhurnal im. N.V. Sklifosovskogo "Neotlozhnaia Meditsinskaia Pomoshch", 2015, no. 3, pp. 23-29. (in Russian)

15.Kutepov S.M., Volokitina E.A., Pomogaeva E.V., Antoniadi Iu.V., Gilev M.V. Dvukhetapnyi metod lecheniia vnutrisustavnykh perelomov distalnogo otdela kostei goleni [Two-stage method of treating intra-articular fractures of the distal tibia bones]. Genij Ortopedii, 2016, no. 3, pp. 21-26. (in Russian)

16.Belenkii I.G., Maiorov B.A., Kochish A.Iu., Usenov M.B. Sovremennye vzgliady na operativnoe lechenie patsientov s perelomami pilona [Modern views on surgical treatment of patients with pilon fractures]. Sovremennye Problemy Nauki i Obrazovaniia, 2018, no. 4. (in Russian) Available at: http://www.science-education.ru/ru/article/view?id=27955 (accessed 11.09.2019).

17.Beytemür O., Albay C., Adanır O., Yüksel S., Güleç M.A. Is intramedullary nailing applicable for distal tibial fractures with ankle joint extension? Eklem. Hastalik. Cerrahisi., 2016, vol. 27, no. 3, pp. 125-131. DOI: 10.5606/ehc.2016.27.

18.Mao Z., Wang G., Zhang L., Zhang L., Chen S., Du H., Zhao Y., Tang P. Intramedullary nailing versus plating for distal tibia fractures without articular involvement: a meta-analysis. J. Orthop. Surg. Res., 2015, vol. 10, pp. 95. DOI 10.1186/s13018-015-0217-5.

19.Xue X.H., Yan S.G., Cai X.Z., Shi M.M., Lin T. Intramedullary nailing versus plating for extra-articular distal tibial metaphyseal fracture: a systematic review and meta-analysis. Injury, 2014, vol. 45, no. 4, pp. 667-676. DOI: 10.1016/j.injury.2013.10.024. 
20.Kumar S., Alwa S., Patil N.G., Vikas H., Patil A., Bansal R., Jolly A., Kamran I. Outcome of distal tibia fractures treated with tibial interlocking nail and minimal invasive plating: A prospective study. International Journal of Orthopaedics Sciences, 2018, vol. 4, no. 1, pp. 802-805. DOI: https://doi.org/10.22271/ortho.2018.v4.i11.116.

21.Hu L., Xiong Y., Mi B., Panayi A.C., Zhou W., Liu Y., Liu J., Xue H., Yan C., Abududilibaier A., Chen L., Liu G. Comparison of intramedullary nailing and plate fixation in distal tibial fractures with metaphyseal damage: a meta-analysis of randomized controlled trials. J. Orthop. Surg. Res., 2019, vol. 14, no. 1, pp. 30. DOI: 10.1186/s13018-018-1037-1.

22.Robinson C.M., McLauchlan G.J., McLean I.P., Court-Brown C.M. Distal metaphyseal fractures of the tibia with minimal involvement of the ankle. Classification and treatment by locked intramedullary nailing. J. Bone Joint Surg. Br., 1995, vol. 77, no. 5, pp. 781-787.

23.Marcus M.S., Yoon R.S., Langford J., Kubiak E.N., Morris A.J., Koval K.J., Haidukewych G.J., Liporace F.A. Is there a role for intramedullary nails in the treatment of simple pilon fractures? Rationale and preliminary results. Injury, 2013, vol. 44, no. 8, pp. 1107-1111. DOI: 10.1016/j.injury.2013.02.014.

Received: 17.09.2019

\section{Information about the authors:}

1.Elena V. Pomogaeva, M.D.,

Ural State Medical University, Ekaterinburg, Russian Federation, Email: plv-2207@mail.ru

2. Elena A. Volokitina, M.D., Ph.D., Ural State Medical University, Ekaterinburg, Russian Federation

3. Sergei M. Kutepov, M.D., Ph.D., Professor, Corresponding Member of RAS

Ural State Medical University, Ekaterinburg, Russian Federation

4. Yury V. Antoniadi, M.D., Ph.D.,

Ural State Medical University, Ekaterinburg, Russian Federation

5. Fedor N. Zverev, M.D.,

Central city clinical hospital № 24, Ekaterinburg, Russia 